\title{
Exogenous fibrolytic enzymes to unlock nutrients: Histological investigation of its effects on fibre degradation in ruminants
}

\author{
W.F.J. van de Vyver ${ }^{\#}$ \& C.W.C. Cruywagen \\ Department of Animal Sciences, Stellenbosch University, Private Bag X1, Matieland 7602, South Africa
}

(Received 11 October 2012; Accepted 14 February 2013; First published online 8 July 2013)

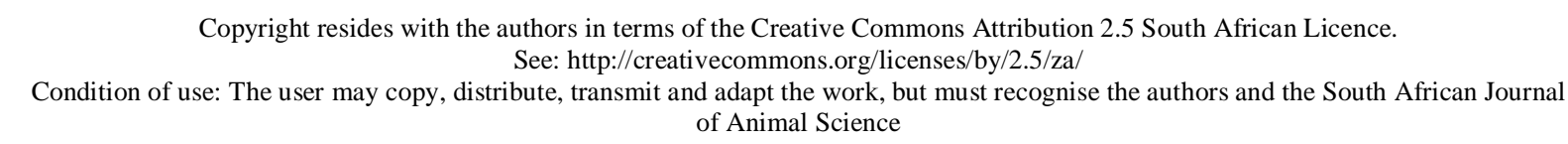

\begin{abstract}
There is a need for a better understanding of the mode-of-action of exogenous fibrolytic enzymes (EFE) used as additives in ruminant feeds. Four forages, treated with EFE, were evaluated in vitro and histologically, in an attempt to determine the effect of EFE on tissue degradation. Weeping love grass, kikuyu leaf material, lucerne and wheat straw stem material were histologically evaluated. Simultaneously, milled samples were incubated in the rumen fluid inoculated media for the determination of in vitro digestibility. The main focus, however, was a quantitative assessment of the degradation of the plant tissue at histological level over a $24 \mathrm{~h}$ incubation period. Degradation of cell wall components were quantified using the image analysis software. After $12 \mathrm{~h}$ of incubation, cell walls of the metaxylem of kikuyu and weeping love grass leaf material were thinner for the EFE treatment than for the control treatment. Treatment also resulted in a significant thinning effect of the cell walls of kikuyu phloem $(12 \mathrm{~h})$ and the adaxial epidermis $(24 \mathrm{~h})$. The abaxial epidermis at $12 \mathrm{~h}$ was thinner for weeping love grass due to EFE treatment. For stem material, a thinning of the epidermis of EFE treated lucerne was observed. Histological findings were concomitant with higher in vitro digestibilities of EFE treated lucerne and kikuyu. It was concluded that image analysis can be useful to quantify changes in cell wall due to the treatment of forages with EFE. There was a definite, subtle thinning effect of EFE on cell wall thickness of plant material which could be indicative of the mode-of-action of EFE.
\end{abstract}

Keywords: Fibre digestion, histology, in vitro digestion

\# Corresponding author: wvdv@sun.ac.za

\section{Introduction}

Additives such as exogenous fibrolytic enzymes (EFE) have been researched worldwide. Promising effects on DMI, digestibility, feed utilization and production in especially dairy cows and feedlot cattle have been demonstrated (Beauchemin et al., 2003; Eun et al., 2007). However, research also points to varied responses of ruminants to EFE treatment of their diets. A better understanding of the mode-of-action of EFE is of importance (Colombatto et al., 2003) as responses vary due to factors such as experimental conditions, dose rate of EFE, method of application, etc. (Beauchemin et al., 1995; 2003). Forage heterogeneity contributes largely to the variation in degradability of plant material even with similar chemical composition but varied anatomy (Travis et al., 1997). It is thus important to recognize the botanical characteristics of plant material as a factor determining its nutritional value (Walters, 1971). Research is limited on the effect of exogenous enzymes on forage tissue at the histological level, although some research points to the effect of EFE at the cellular level. Recently, it has been reported that EFE alters the fibre structure of plant material (Giraldo et al., 2008). The objectives of this study was to determine the effect of EFE on in vitro digestibility of kikuyu (Pennisetum clandestinum) hay, weeping love grass (Eragrostis curvula) hay, lucerne 
(Medicago sativa) hay and wheat (Triticum spp.) straw and to quantitatively assess the degradation of the plant tissues at histological level when treated with EFE and incubated in vitro in buffered rumen fluid.

\section{Materials and Methods}

For the histological investigation, leaf material of freshly cut weeping love grass (Eragrostis curvula) and kikuyu (Pennisetum clandestinum) and stem material of freshly cut lucerne (Medicago sativa) and wheat straw (Triticum) were collected and prepared for sectioning by infusion of tissue with tissue freezing medium (Cryo-M-Bed, embedding compound, Bright Instrument Company Ltd, Huntingdon, England) prior to cryofreezing in liquid nitrogen. Cross sections $(20 \mu \mathrm{m})$ were made on a cryostat and fixed to microscope slides (Lasec $^{\mathrm{TM}}$ ) by means of clear double-sided tape, as described by Akin (1982). Two slides (containing three sections each) were incubated back to back in $50 \mathrm{~mL}$ glass test tubes. Two test tubes per treatment (EFE or Control) were allowed per incubation time and the whole experiment was duplicated. Incubation times were $0 \mathrm{~h}$ (no incubation), $6 \mathrm{~h}, 12 \mathrm{~h}$ and $24 \mathrm{~h}$ in buffered rumen fluid. The EFE was a dilution of $1 \mathrm{~mL}$ ABO 374 supernatant in $200 \mathrm{~mL}$ distilled water, of which $1 \mathrm{~mL}$ was added to each slide in the test tubes. The ABO 374 supernatant contained xylanases (296 $\pm 0.07 \mathrm{U} / \mathrm{mg}$ protein), cellulases $(1.44 \pm 0.39 \mathrm{U} / \mathrm{mg}$ protein) and mannanases $(1.10 \pm 0.37 \mathrm{U} / \mathrm{mg}$ protein) as the major fibrolytic enzyme components (Cruywagen \& Van Zyl, 2008). Slides were pre-treated with EFE or distilled water for $12 \mathrm{~h}$ in glass tubes sealed with rubber stoppers prior to incubation in buffered rumen fluid. To the tubes containing the slides, $40 \mathrm{~mL}$ buffer (pH 6.8) and 10 $\mathrm{ml}$ filtered and blended rumen fluid was added under strict anaerobic conditions. Rumen fluid was collected prior to the morning feeding from two cannulated sheep, filtered through four layers of cheesecloth and blended for 30 seconds before being added to the buffer. Sheep were maintained on a lucerne hay and oat hay diet (50:50 mixture) and supplemented with $250 \mathrm{~g} / \mathrm{d}$ of a commercial feed concentrate. The tubes were sealed with rubber stoppers under $\mathrm{CO}_{2}$ gas phase and incubated in a shaking water bath at $39{ }^{\circ} \mathrm{C}$. After the appropriate incubation periods, slides (two per treatment) were randomly removed from the test tubes, rinsed in ice cold water and stained with Toluidine blue for 5 minutes. They were subsequently rinsed and covered with a cover slip to prevent the sample from drying out. Samples were observed on an Olympus Cell ${ }^{\mathrm{R}}$ system attached to an IX-81 inverted microscope equipped with a F-view-II cooled CCD camera (Soft Imaging Systems). Images were acquired by using Olympus 40x (leaf material) and 4x objectives (stem material) and the Cell ${ }^{\mathrm{R}}$ imaging software. The total magnification was $400 \mathrm{x}$ or $40 \mathrm{x}$, respectively for leaf and stem material when the 10x ocular piece's magnification is calculated as well. Images were analysed using the Cell ${ }^{\mathrm{R}}$ software (Olympus Biosystems GMBH, Muenster, Germany).

In vitro digestibility was evaluated according to the method for "In vitro true digestibility using the DAISY incubator” as described by ANKOM Technology, Fairport, NY. Samples were milled through a 1.5 mm screen and sieved before being weighed $(0.5 \mathrm{~g})$ into F57 filter bags. Samples were then pre-treated with EFE as described earlier, or distilled water (control) for a period of $12 \mathrm{~h}$ prior to incubation in buffered rumen fluid. Bags were removed and analysed after $24 \mathrm{~h}$ of incubation.

The in vitro digestibility data were subjected to a Factorial ANOVA, whereas histology data were analyzed with either a Bonferroni or Newman-Keuls multifactorial test, using Statistica 8.1 (2008).

\section{Results and Discussion}

The cell types observed and measured for cell wall thickness were the abaxial and adaxial epidermis, the metaxyleme, xyleme, phloem island cells and the parenchyma bundle sheath. These structures are presented in Figure 1, using kikuyu and weeping love grass as examples. For the stem material, in addition to the cell wall thickness of the epidermis, the total tissue surface area was also determined.

It can be seen in Figure 2 (using kikuyu leaf material as example) how the tissue structures of the Control and EFE treated specimens were degraded after $24 \mathrm{~h}$ of incubation in buffered rumen fluid. The degradation of the plant tissues observed here is in agreement with the findings of Buxton \& Readfearn (1997). These authors found that mesophyll was highly digestible, while parenchyma, collechyma and parenchyma bundle sheaths were moderately to highly digestible. The structural components of epidermis, vascular tissue and schlerenchyma have low digestibilities, or can even be indigestible.

The cell wall thickness values and surface areas of the EFE and Control specimens following incubation were computed and the reduction in cell wall thickness and surface areas were determined. The reduction in cell wall thickness was used as indication of the effect of EFE treatment on fibre digestion and is presented in Table 1 (leaf specimens) and Table 2 (stem specimens). From Table 1, it can be seen that EFE 
resulted in thinner $(P<0.05)$ adaxial epidermis (kikuyu $24 \mathrm{~h})$ and abaxial epidermis (weeping love grass $12 \mathrm{~h}$ ) values compared to the Control. Treatment also decreased metaxylem cell wall thickness for both kikuyu and weeping love grass at $12 \mathrm{~h}$ of incubation. Phloem cell walls were thinner only for kikuyu after $12 \mathrm{~h}$ incubation $(P<0.05)$. Metaxylem, expressed as a percentage surface area of the unincubated $(0 \mathrm{~h})$ kikuyu specimen, was also decreased by EFE treatment $(P<0.05)$. For the stem material investigated (Table 2 ), the only significant observation $(P<0.05)$ was a decrease in the epidermal cell wall thickness of lucerne at $12 \mathrm{~h}$ of incubation in buffered rumen fluid with EFE.

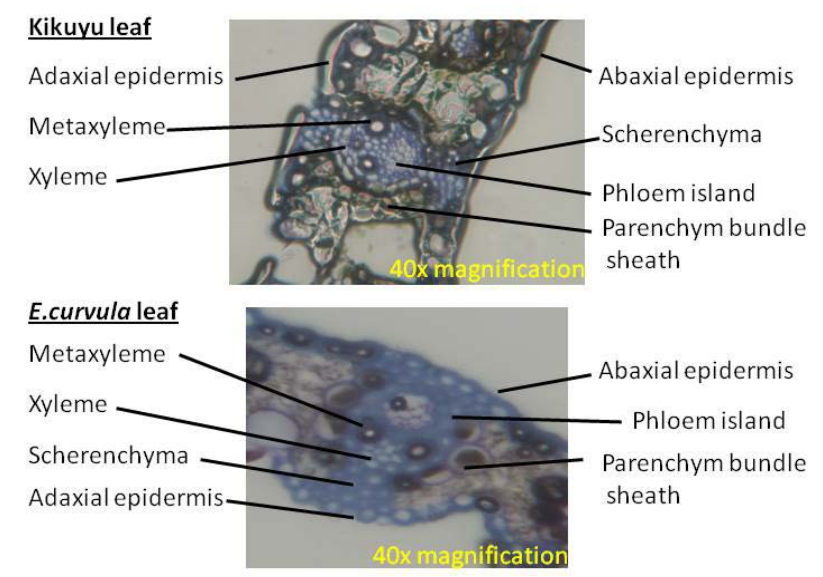

Figure 1 Histology of undigested kikuyu and weeping love grass leaf material determined with 40x magnification lenses and 10x ocular piece of a conventional light microscope (Olympus).

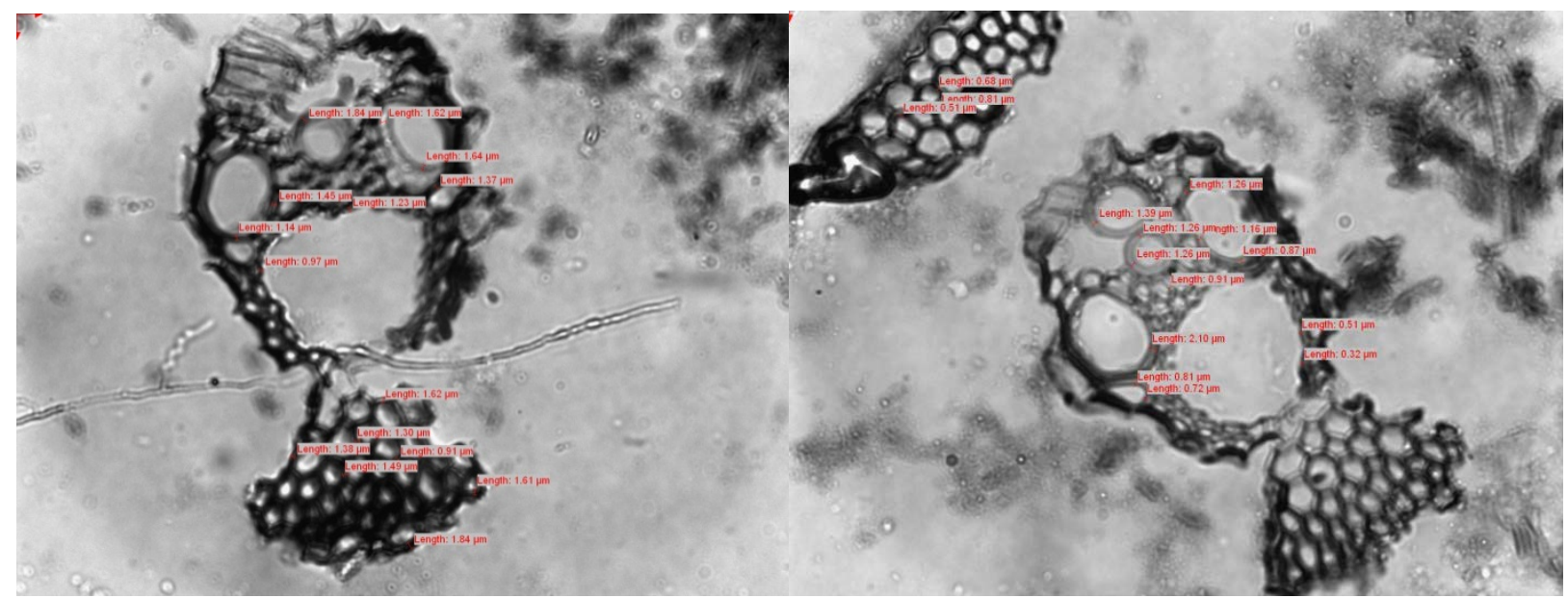

Figure 2 Degradation of kikuyu leaf material treated with $\mathrm{dH}_{2} \mathrm{O}$ (left) or EFE (right) after $24 \mathrm{~h}$ incubation in buffered rumen fluid. The cell wall thickness of the appropriate tissue types was determined using Cell ${ }^{\mathrm{R}}$ imaging software (Soft imaging systems).

Overall, EFE resulted in a subtle reduction of cell wall thickness of the various tissues studied. This is based on the calculation of the percentage reduction in cell wall thickness from $0 \mathrm{~h}$ to $12 \mathrm{~h}$ and $24 \mathrm{~h}$ of the EFE treatment compared with the control. 
Table 1 Mean $( \pm$ SE) cell wall thickness (CWT) of EFE-treated kikuyu or weeping love grass tissues after in vitro digestion in buffered rumen fluid

\begin{tabular}{|c|c|c|c|c|c|c|c|c|c|c|c|}
\hline $\begin{array}{c}\text { Cross } \\
\text { sections } \\
\text { of leaves }\end{array}$ & Treatment & $\begin{array}{l}\text { Ad. Epi. } \\
\text { CWT, } \mu \mathrm{m}\end{array}$ & $\begin{array}{c}\text { Reduction } \\
\text { in CWT } \\
\text { from 0h, } \\
\% \\
\end{array}$ & $\begin{array}{l}\text { Ab. Epi. } \\
\text { CWT, } \mu \mathrm{m}\end{array}$ & $\begin{array}{c}\text { Reduction } \\
\text { in CWT } \\
\text { from 0h, } \\
\%\end{array}$ & $\begin{array}{l}\text { Metaxyl. } \\
\text { CWT, } \mu \mathrm{m}\end{array}$ & $\begin{array}{c}\text { Reduction } \\
\text { in CWT } \\
\text { from } 0 \mathrm{~h} \text {, } \\
\% \\
\end{array}$ & $\begin{array}{l}\text { Phl. } \\
\text { CWT, } \\
\mu \mathrm{m}\end{array}$ & $\begin{array}{c}\text { Reduction } \\
\text { in CWT } \\
\text { from 0h, } \\
\% \\
\end{array}$ & $\begin{array}{c}\text { Metaxyl. } \\
\text { expressed as } \\
\text { surface area, } \\
\mu^{2} \\
\end{array}$ & $\begin{array}{c}\text { Reduction } \\
\text { in AOI } \\
\text { from 0h, } \\
\%\end{array}$ \\
\hline \multirow[t]{7}{*}{ Kikuyu } & Cnt $0 \mathrm{~h}$ & $\begin{array}{c}1.43 \pm \\
0.05\end{array}$ & 0 & $\begin{array}{c}1.59 \pm \\
0.07\end{array}$ & 0 & $\begin{array}{c}1.49 \pm \\
0.17\end{array}$ & 0.00 & $\begin{array}{c}1.43 \pm \\
0.20\end{array}$ & 0 & $\begin{array}{c}306.00 \pm \\
40.49\end{array}$ & 0.00 \\
\hline & Cnt 6h & $\begin{array}{c}1.44 \pm \\
0.07\end{array}$ & 0 & $\begin{array}{c}1.68 \pm \\
0.01\end{array}$ & 0 & $\begin{array}{c}1.32 \pm \\
0.09\end{array}$ & 11.66 & $\begin{array}{c}1.25 \pm \\
0.10\end{array}$ & 12.7 & $\begin{array}{c}372.83 \pm \\
61.23\end{array}$ & -21.84 \\
\hline & EFE 6h & $\begin{array}{l}1.32 \pm \\
0.35\end{array}$ & 6.95 & $\begin{array}{c}1.45 \pm \\
0.01\end{array}$ & 8.5 & $\begin{array}{c}1.38 \pm \\
0.13\end{array}$ & 7.66 & $\begin{array}{c}1.34 \pm \\
0.08\end{array}$ & 6.2 & $\begin{array}{c}364.64 \pm \\
57.09\end{array}$ & -19.16 \\
\hline & Cnt 12h & $\begin{array}{c}1.31 \pm \\
0.11\end{array}$ & 7.82 & $\begin{array}{c}1.64 \pm \\
0.14\end{array}$ & 0 & $\begin{array}{c}1.42^{\mathrm{a}} \pm \\
0.05\end{array}$ & 4.96 & $\begin{array}{c}1.41^{\mathrm{a}} \pm \\
0.09\end{array}$ & 1.3 & $\begin{array}{c}240.99 \pm \\
65.06\end{array}$ & 21.24 \\
\hline & EFE $12 \mathrm{~h}$ & $\begin{array}{c}1.33 \pm \\
0.02\end{array}$ & 6.92 & $\begin{array}{c}1.70 \pm \\
0.00\end{array}$ & 0 & $\begin{array}{c}1.03^{\mathrm{b}} \pm \\
0.01\end{array}$ & 30.69 & $\begin{array}{c}1.12^{\mathrm{b}} \pm \\
0.20\end{array}$ & 21.6 & $\begin{array}{c}232.06 \pm \\
63.55\end{array}$ & 24.16 \\
\hline & Cnt 24h & $\begin{array}{c}1.34^{\mathrm{a}} \pm \\
0.09\end{array}$ & 5.75 & $\begin{array}{c}1.37 \pm \\
0.15\end{array}$ & 13.58 & $\begin{array}{c}1.18 \pm \\
0.10\end{array}$ & 21.12 & $\begin{array}{c}1.00 \pm \\
0.08\end{array}$ & 29.7 & $\begin{array}{c}288.41^{\mathrm{a}} \pm \\
92.85\end{array}$ & 5.75 \\
\hline & EFE 24h & $\begin{array}{c}1.11^{\mathrm{b}} \pm \\
0.01\end{array}$ & 22.4 & $\begin{array}{c}1.32 \pm \\
0.01\end{array}$ & 16.44 & $\begin{array}{c}1.05 \pm \\
0.10\end{array}$ & 29.20 & $\begin{array}{c}1.02 \pm \\
0.20\end{array}$ & 28.7 & $\begin{array}{c}176.96^{\mathrm{b}} \pm \\
20.09\end{array}$ & 42.17 \\
\hline \multirow{3}{*}{$\begin{array}{l}\text { Weeping } \\
\text { love } \\
\text { grass }\end{array}$} & Cnt 0h & $\begin{array}{c}1.61 \pm \\
0.16\end{array}$ & 0 & $\begin{array}{c}1.79 \pm \\
0.29\end{array}$ & 0 & $\begin{array}{c}1.14 \pm \\
0.09\end{array}$ & 0.00 & $\begin{array}{c}1.17 \pm \\
0.00\end{array}$ & 0 & $\begin{array}{c}249.37 \pm \\
9.10\end{array}$ & 0.00 \\
\hline & Cnt 12h & $\begin{array}{c}1.45 \pm \\
0.04\end{array}$ & 9.9 & $\begin{array}{c}1.92^{\mathrm{a}} \pm \\
0.33\end{array}$ & 0 & $\begin{array}{c}1.12^{\mathrm{a}} \pm \\
0.01\end{array}$ & 2.00 & $\begin{array}{c}1.12 \pm \\
0.26\end{array}$ & 4.1 & $\begin{array}{c}241.12 \pm 39 \\
19\end{array}$ & 3.31 \\
\hline & EFE $12 \mathrm{~h}$ & $\begin{array}{c}1.54 \pm \\
0.00\end{array}$ & 4.3 & $\begin{array}{c}1.39^{\mathrm{b}} \pm \\
0.50\end{array}$ & 22.3 & $\begin{array}{c}0.71^{\mathrm{b}} \pm \\
0.00\end{array}$ & 37.37 & $\begin{array}{c}0.97 \pm \\
0.16\end{array}$ & 16.9 & $\begin{array}{c}243.89 \pm \\
22.87\end{array}$ & 2.20 \\
\hline
\end{tabular}

Ad. = adaxial, Ab. - abaxial, Epi. = epidermis, CWT = cell wall thickness, Xyl. = xyleme, Metaxyl. = metaxyleme, Phl. = phloem, AOI = area of interest. Means in the same column with different superscripts differed significantly $(P<0.05)$. 
These findings support the hypothesis that EFE can degrade cell wall structures, thereby allowing ruminal microbes earlier access to fermentable substrate during the initial phase of digestion (Colombatto et al., 2003). Should the cell wall structures be weakened or altered in such a way as to allow earlier access of microbes to the cell contents as proposed here, it follows that the digestibility could be positively influenced. This was observed in the current study (Figure 3) where the $24 \mathrm{~h}$ in vitro digestibility of kikuyu and lucerne was increased by EFE treatment. The in vitro digestibility of EFE treated lucerne hay (770.0 $\mathrm{g} / \mathrm{kg})$ was higher $(P=0.008)$ than that of the control $(747.0 \mathrm{~g} / \mathrm{kg})$. Similarly, EFE resulted in an increase in in vitro digestibility from $619.0 \mathrm{~g} / \mathrm{kg}$ (Control) to $654.0 \mathrm{~g} / \mathrm{kg}$ for the EFE treated kikuyu sample $(P=0.004)$. No treatment effects on the digestibility of weeping love grass or wheat straw were observed.

Table 2 Mean ( \pm SE) cell wall thickness (CWT) and surface area measurements of EFE-treated lucerne and wheat straw tissues after in vitro digestion in buffered rumen fluid

\begin{tabular}{|c|c|c|c|c|c|c|c|}
\hline $\begin{array}{l}\text { Cross } \\
\text { sections of } \\
\text { stems }\end{array}$ & Treatment & $\begin{array}{c}\text { Epidermis } \\
\text { CWT } \\
\mu \mathrm{m}\end{array}$ & $\begin{array}{l}\text { Reduction } \\
\text { in CWT } \\
\text { from 0h, \% }\end{array}$ & $\begin{array}{c}\text { Inner } \\
\text { mambrane } \\
\text { CWT, } \mu \mathrm{m}\end{array}$ & $\begin{array}{c}\text { Reduction } \\
\text { in CWT } \\
\text { from 0h, \% }\end{array}$ & $\begin{array}{c}\text { Material } \\
\text { surface area } \\
\text { as \% of total }\end{array}$ & $\begin{array}{c}\text { Reduction } \\
\text { in area from } \\
\text { 0h, \% }\end{array}$ \\
\hline \multirow[t]{7}{*}{ Lucerne } & Cnt Oh & $13.0 \pm 0.48$ & 0.0 & $7.60 \pm 0.25$ & 0.00 & $66.6 \pm 2.41$ & 0.0 \\
\hline & Cnt 6h & $9.24 \pm 0.83$ & 28.9 & $7.55 \pm 1.35$ & 0.71 & $52.1 \pm 6.98$ & 21.8 \\
\hline & EFE 6h & $9.36 \pm 0.43$ & 27.9 & $6.76 \pm 0.19$ & 11.11 & $47.4 \pm 1.19$ & 28.9 \\
\hline & Cnt $12 \mathrm{~h}$ & $8.77^{\mathrm{a}} \pm 0.46$ & 32.5 & $7.39 \pm 0.19$ & 2.82 & $29.9 \pm 3.27$ & 55.1 \\
\hline & EFE $12 \mathrm{~h}$ & $7.39^{b} \pm 0.59$ & 43.1 & $6.78 \pm 0.21$ & 10.87 & $30.9 \pm 1.79$ & 53.6 \\
\hline & Cnt 24h & $8.48 \pm 0.53$ & 34.7 & $6.51 \pm 0.99$ & 14.37 & $23.7 \pm 0.84$ & 64.4 \\
\hline & EFE 24h & $7.87 \pm 0.17$ & 39.5 & $6.48 \pm 0.34$ & 14.71 & $23.7 \pm 2.17$ & 64.4 \\
\hline \multirow{3}{*}{$\begin{array}{l}\text { Wheat } \\
\text { straw }\end{array}$} & Cnt Oh & $13.02 \pm 1.22$ & 0.0 & $11.89 \pm 1.20$ & 0.00 & $70.9 \pm 0.72$ & 0.0 \\
\hline & Cnt $12 \mathrm{~h}$ & $9.27 \pm 0.70$ & 28.8 & $8.73 \pm 0.78$ & 26.59 & $66.7 \pm 1.38$ & 5.9 \\
\hline & EFE $12 \mathrm{~h}$ & $9.11 \pm 0.91$ & 29.9 & $6.28 \pm 0.99$ & 47.23 & $66.7 \pm 0.90$ & 6.0 \\
\hline
\end{tabular}

CWT $=$ cell wall thickness. Values with different superscripts differed significantly $(P<0.05)$.

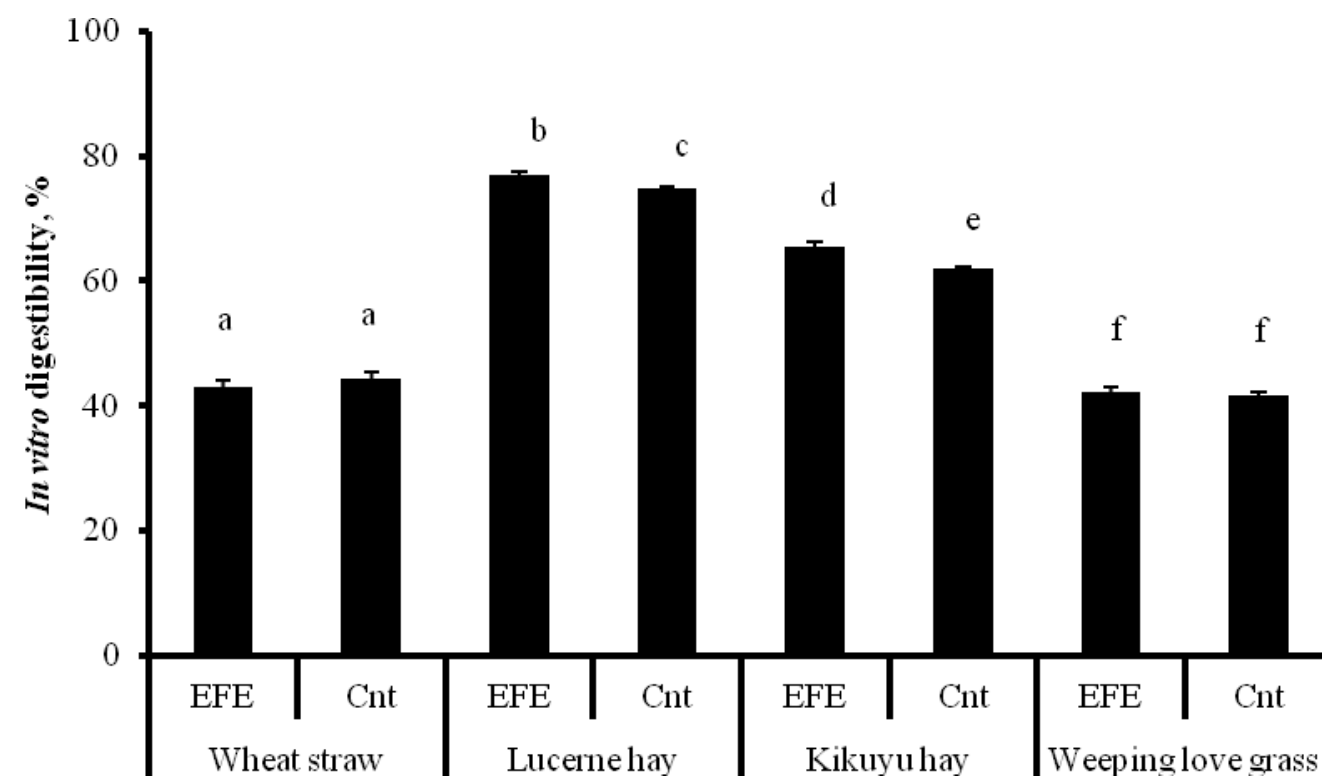

Figure 3 Mean in vitro digestibility of forages treated with EFE or distilled water and incubated in buffered rumen fluid for 24h. Error bars represent the SEM. Different superscripts depicted at the bars indicate significance at $P<0.05$. 


\section{Conclusion}

Results from this study suggest that exogenous fibrolytic enzymes have a thinning effect on the cell wall components of plant material which was substantiated by improved in vitro digestibility of EFE treated samples. Although limited significant effects were reported in terms of cell wall thinning of the various tissues studied, the key to the observations were that subtle effects were indeed observed. This is in strong agreement with literature where effects on cell wall digestion have been proposed by several researchers as a contributing factor to the mode-of-action of EFE. It was concluded that EFE altered fibre cell wall structures, thereby positively influencing fibre digestion.

\section{Acknowledgments}

The authors express gratitude to the NRF and subcommittee B of Stellenbosch University for funding of the project. The Department of Microbiology, Stellenbosch University is acknowledged for the supply of the exogenous enzyme (ABO 374).

\section{References}

Akin, D.E., 1982. Section to slide technique for study of forage anatomy and digestion. Crop Sci. 22, 444-446.

Beauchemin, K.A., Colombatto, D., Morgavi, D.P. \& Yang, W.Z., 2003. Use of exogenous fibrolytic enzymes to improve feed utilization by ruminants. J. Anim. Sci. 81 (E. Suppl. 2), E37-E47.

Beauchemin, K.A., Rode, L.M. \& Sewalt, V.J.H., 1995. Fibrolytic enzymes increase fiber digestibility and growth rate of steers fed dry forages. Can. J. Anim. Sci. 75, 641-644.

Buxton, D.R. \& Redfearn, D.D., 1997. Plant limitations to fibre digestion and utilization. J. Nutr. 127, 814S-818S.

Colombatto, D., Mould, F.L., Bhat, M.K. Morgavi, D.P., Beauchemin, K.A. \& Owen, E., 2003. Influence of fibrolytic enzymes on the hydrolysis and fermentation of pure cellulose and xylan by mixed ruminal microorganisms in vitro. J. Anim. Sci. 81, 1040-1050.

Cruywagen, C.W. \& Van Zyl, W.H., 2008. Effects of a fungal enzyme cocktail treatment of high and low forage diets on lamb growth. Anim. Feed Sci. Technol. 145, 151-158.

Eun, J.-S., Beauchemin, K.A. \& Schulze, H., 2007. Use of exogenous fibrolytic enzymes to enhance in vitro fermentation of alfalfa hay and corn silage. J. Dairy Sci. 90, 1440-1451.

Giraldo, L.A., Tejido, M.L., Ranilla, M.J., Ramos, S. \& Carro, M.D., 2008. Influence of direct-fed fibrolytic enzymes on diet digestibility and ruminal activity in sheep fed a grass hay-based diet. J. Anim. Sci. 86, 1617-1623.

Statsoft, 2008. Statistica version 8.1, StatSoft, Inc., Tulsa, OK.

Travis, A.J., Murison, S.D., Perry, P. \& Chesson, A., 1997. Measurement of cell wall volume using confocal microscopy and its application to studies of forage degradation. Annals Bot. 80, 1-11.

Walters, R.J.K., 1971. Variation in the relationship between in vitro digestibility and voluntary dry matter intake of different grass varieties. J. Agric. Sci. 76, 243-252. 